\title{
5 Abolishing asylum and violating the human rights of refugees. Why is it tolerated?
}

The case of Hungary in the EU

Felix Bender

\section{Introduction}

And at this point, Dear Friends, I must also say a few words about the dispute between Western and Central Europe. It seems that the courses of development of these two parts of Europe have diverged.... The great old European nations in Western Europe have become immigrant countries. Day by day their cultural foundations are being transformed, the population raised in a Christian culture is declining, and the major cities are undergoing Islamization.... We have prevented are the last country in Latin - or Western - Christianity. We are standing firm.

(Orbán 2018a)

The basic right of asylum applies to all persons persecuted on political grounds. We can be proud of the humanity of our constitution. It reveals itself especially in this article. We also provide protection to those who flee to us from war zones. They, too, are owed protection.

(Merkel 2015, own translation)

The two statements below could not differ more.

Contemporary Europe is witnessing a rift. On the one hand, core EU member states, such as Germany, rhetorically affirm their fidelity towards the institution of asylum. 'Persons persecuted on political grounds shall have the right of asylum,' reads Article 16a of the Basic Law (Basic Law for the Federal Republic of Germany, 1949). The German government has been lauded for upholding the normative principle that lies at the core of this article in its response to the 'refugee crisis' of 2015 (Betts 2015; Ignatieff 2017). It has been seen as defending the principle that asylum must remain a fundamental right available to all who apply for it.

On the other hand, we are witnessing the emergence of a different norm: a norm of closure, celebrated by several countries at the periphery of the European Union, but most notably by Hungary. Rhetoric, such as the 
above, underlines the construction of walls, open hostility towards foreigners, and violence against them.

It would be too easy to be satisfied with an answer to the question of how this rift came about. Instead, we must seek the answer to the question: why does it remain? This chapter seeks to answer this question. It seeks to explain why we are witnessing so little resistance against the abuse of human rights and the de-facto abolition of the institution of asylum in Hungary by states that seemingly cherish the normative principle underlying the right to seek asylum. In other words, it aims to explain how these two distinct positions relate to each other.

Before answering the question posed above, we need to elaborate on the definition of the rift itself. What does the norm of closure, celebrated by Hungary's politicians, entail? How does it differ from a fundamental fidelity towards the institution of asylum? Only after we answer these questions, can we try to explain why the rift persists. The answer this chapter gives is simple. The rift remains, because these seemingly contrary positions necessitate each other. Core EU countries, such as Germany, can only position themselves as states that uphold and defend the principle underlying asylum, if countries at the periphery of the EU deny asylum seekers access to their territories. Conversely, core EU countries condone the treatment of refugees at the EU periphery, even if it implies human rights abuses and the de facto abolition of the institution of asylum. The result is a 'division of labor.' Core EU countries may portray themselves as morally untainted. They enshrine and uphold the fundamental right of asylum, while countries such as Hungary may reap the political fruits of a norm of closure, as long as they keep refugees at bay. In this context, it seems easy to condemn the latter. And we should. What we might learn, however, is that the former are not as morally untainted as we might have thought.

I suggest to first look at what the norm of closure entails. Although we can observe different countries testing the limits of such a norm, none has done so to the same degree as Hungary. Therefore, in the first section of this chapter, I explain what makes the norm of closure special and what it entails. I show that said norm entails the abolition of the institution of asylum and what this means for the treatment of refugees. The second part of the chapter concerns the question of why the abolition of the institution of asylum and the human rights abuses of refugees at the EU periphery are condoned by states at the territorial core of the EU. I ask why this is the case even though states such as Germany seemingly cherish the normative principle underlying the right of asylum. It should be noted that this chapter is mainly concerned with the politics and policies regarding refugees after the so-called refugee crisis of 2015. I do not discuss the situation in Hungary and Germany during the events of the 'long summer of migration.' ${ }^{1}$ Rather, I am interested in the events and the politics that ensued. 


\section{Dominating refugees: the abolition of the institution of asylum in Hungary}

\section{Abolishing asylum}

In early 2015, the rift was nothing more than a crack. The Hungarian state possessed a somewhat functioning asylum system. ${ }^{2}$ Its politicians were, by and large, not very interested in the topic of migration. This changed as the year progressed. The reasons for this change are not very clear. It may have been related to mounting dissatisfaction with government policies - the government had just proposed a hugely unpopular tax on internet use leading to politicians searching for alternative topics to reel in the public. Or it may have had to do with the realization of Hungarian politicians that fighting a foreign enemy (real or imagined) allows for the creation of a partyoverarching 'We' - a national identity to rally behind (Nagy 2016). Whatever the reasons for the change might have been, we are not interested in the origins of the policies that were about to follow, but rather in their effects. Thus, let us focus on the latter.

Shortly after hundreds of thousands of refugees had made their way across what they regarded as a country of transit up until September 2015, Hungary decided to put a stop to the movement of refugees. In the summer of 2015, it announced that it would build a fence along its entire $175 \mathrm{~km}-$ long border with Serbia, aimed at keeping refugees at bay. The Minister heading the Hungarian Prime Minister's Office, János Lázár, justified the construction of the fence by referring to the necessity of orderly migration: 'we are conservative people; we insist that if you want to enter someone's house, you must knock first, rather than break down the wall' (2015). Yet, the fence did not establish orderly migration. It aimed to put a halt to migration altogether. It was the first step towards the abolition of a principally applied right to asylum. The creation of a physical barrier at the border with Serbia was only part of the construction of an order that sought to control the movement of refugees and aimed at detaining and deterring refugees. This order, aimed at the abolition of the institution of asylum, entails much more than just blocking the paths of refugees. It entails establishing control over refugees within the demarcation lines that we call the border. ${ }^{3}$ Both subject refugees to a regime of violence.

The construction of the fence was accompanied by the establishment of transit zones at the border, which function as barbed wire fenced detention centers, holding refugees until their refoulement. Moreover, it was accompanied by a bevy of laws, deteriorating the institution of asylum, and constructing a regime aimed at sealing the borders at any price.

The first wave of laws restructuring the order controlling refugees came into force on the day the border fence was officially completed: September 15,2015 . The new regulations aimed to criminalize the border crossings of refugees and make seeking asylum a criminal offense if not performed in 'the orderly way' the government foresaw. Refugees crossing anywhere at the 


\section{F. Bender}

border, and not at the newly established transit zones, would now be punished by a prison sentence of up to one year, expelled from the country, and banned from re-entry. Even stricter forms of punishment awaited those who damage the fence while crossing the border. This newly created offense could result in a prison sentence of up to three years. Between September 2015 and December 2016, this law resulted in 3,000 cases being brought before court (Binetti Armstrong 2018). Most of them ended in convictions. Of course, entering Hungarian territory anywhere but the transit zones could only be achieved through damaging the newly erected fence, which meant that anyone caught doing so would be liable to serve between one and three years in prison. The law serves as a potential blanket justification for denying those who cross the border at locations other than the designated spots and stands the right to seek asylum, of course, in blatant contradiction to international law (Hungarian Helsinki Committee 2015a).

The orderly way, according to the Hungarian Government, was for refugees to enter through the newly created transit zones either at the border with Serbia or Croatia. Yet, access to these transit zones was never unlimited. The transit zones, which were de facto detention centers consisting of container camps, surrounded by razor wire, and guarded by armed police, were never accessible to anyone who wanted to launch an asylum procedure. Since their establishment in 2015, the number of people admitted daily was steadily reduced by the Hungarian state from 30 to only two - one person per transit zone and per work-day (Hungarian Helsinki Committee 2018a). The transit zones themselves were established solely on Hungarian soil, leaving a stretch of land beyond these zones on Hungarian territory, too. This stretch of land between the zones and Serbian territory was aptly described by NGOs as a 'no man's land' (Hungarian Helsinki Committee 2016a; Binetti Armstrong 2018). The Hungarian state refused to assume responsibility for the refugees remaining in it, and the international organizations that sought to organize support for those stranded there had difficulties doing so, since they were not invited by the Hungarian state to distribute aid to refugees remaining on Hungarian soil. The order that the Hungarian state had established thus reached beyond the immediate barriers erected. Since admission was restricted and no procedure existed to determine who was to enter next, refugees were kept in limbo beyond the fence. At times, thousands camped in front of the transit zones without basic support, with thousands returning to Serbia to live in squalid conditions in a country without a functioning asylum system (Umek, Minca \& Šantić 2019). Thus, even though refugees had already entered Hungary and the state's international legal responsibilities were clear, their claims to enter asylum procedures were denied as a consequence of the new legislation (Hungarian Helsinki Committee 2016a; 2018e).

These legislative changes also had a profound impact on ordering the lives of the refugees who made it to the parts of the country in which the Hungarian state still claimed responsibility for administering asylum claims. They 
profoundly changed the asylum procedure, including admission criteria, application procedures, and access to effective remedies.

The legislative package introduced a number of additional countries as safe third countries. Once they enter the transit zones and after initial checks for competency according to the Dublin regulations, asylum seekers' applications must be checked for admissibility. The safe third country rule allowed for deeming applications inadmissible if the applicant had passed through and could have lodged an asylum application in a safe third country before having lodged an asylum procedure in Hungary. In 2015, Serbia was included on this list (cf. Hungarian Helsinki Committee 2015b; Binetti Armstrong 2018). This means that all asylum applications lodged by persons that have travelled through Serbia were ruled inadmissible from the outset unless refugees could provide evidence for being unsafe in Serbia. Since the vast majority of refugees travel through Serbia to reach Hungary, the regulation results in over $99 \%$ of the refugees applying for asylum in Hungary being automatically rejected (Hungarian Helsinki Committee 2015b). The decision on admissibility, according to the new law, is to be taken within eight days. Yet, in practice, decisions are often reached in less than one hour (Asylum Information Database 2017). After a negative decision, refugees are given only three days to disagree with it and prove why these 'safe third countries' are not safe in their individual cases. In many instances, however, refugees are given a prepared document to sign, stating their disagreement with the negative decision. This document serves as the basis for immediately rejecting such requests by the immigration office. This occurs without considering the refugee's statement and without the refugee being able to consult legal advisors. Following this decision, refugees are again given only three days to appeal it - not enough time to prepare for a court hearing. All in all, refugees are unable to legally challenge inadmissibility decisions effectively, which constitutes a violation of the right to an effective remedy (Asylum Information Database 2017). Consequently, they are then supposed to return to the relevant safe third country. Serbia, however, refuses to take back any refugees from Hungary. For refugees, this often means that following an inadmissibility decision, they are simply 'escorted' out of the transit zone. They still find themselves on Hungarian territory, but beyond the border fence and banned from re-entry for one or two years. The order that the Hungarian state imposes creates refugees that exist in orbit - they are not legally admitted to Hungary or to Serbia. What this means is a life in the shadows and for many this meant simply returning to the camps in Serbia, if one did not want to run the risk of re-entering Hungary elsewhere.

These are, of course, not the only changes made to the institutional structure regulating asylum procedures in Hungary. An order that aims to completely control the lives of refugees and to abolish the institution of asylum, cannot issue control over parts of this system. It must also encompass those attempting to defend the rights of refugees and the institution of asylum itself. 


\section{F. Bender}

A final shift towards the abolition of the right to asylum and, thus, the last brick in building a norm of closure came in 2018. In June, the Parliament passed a legislative package called 'Stop Soros' that effectively excluded civil society actors from asylum procedures. The laws threatened severe punishments, ranging from banishment from border areas to prison sentences, for those assisting asylum seekers legally or materially before their asylum status was confirmed (Hungarian Helsinki Committee 2018b). This served the purpose of reducing the probability of refugees to receive asylum. By restraining the observing function of civil society actors and their capabilities of intervening in asylum procedures, the state administration and court system were given a wider range of discretion in operating and deciding the outcome of such procedures. Refugees without legal assistance can be denied asylum more easily.

In the context of minimizing the role of civil society organizations and maximizing the discretionary power of administrative bodies and courts, the Hungarian government proceeded to add further significant restrictions to asylum procedures. In December 2018, the Parliament passed constitutional amendments that effectively replaced the safe third country rule with an article that is simultaneously less specific and more restrictive. ${ }^{4}$ The article replaces the idea of providing a list of countries, in which refugees are effectively able to seek asylum and are hence safe with a general clause that stipulates safety for refugees in any country in which they do not fear persecution. The difference between the two is significant. The new formulation offers asylum only to those who have entered Hungary directly from the state in which they fear persecution. Crossing any other state in which a fear of persecution cannot be demonstrated leads to the rejection of an asylum claim, even if seeking asylum in these states is not feasible.

These legal changes reverse both the interpretation of safety and the onus of proof. While asylum claims could formerly be rejected only if the safety of refugees could be demonstrated elsewhere, they can now be rejected on the grounds that they are not unsafe elsewhere. Therefore, one must no longer prove their safety, but merely a lack of persecution. This also places the onus of proof on the refugee. The state must no longer justify to refugees why they would be safe elsewhere. Instead, it is now up to the refugees themselves to justify why they would not be safe elsewhere.

The intimidation of and the control over all agents involved in the asylum process would not be complete without seizing control over the institutions that provide the final legal decisions over matters of asylum. To this end, the Hungarian government has stripped the Constitutional Court of the country of its powers in ruling on administrative cases. With the constitutional changes, a parallel high court, called the Administrative High Court, was introduced that assumed these responsibilities, including the authority to issue final rulings on asylum cases (amongst others) and with the power to issue interpretative guidance in applying the law to lower courts. The president of this newly founded court is elected by the Parliament (cf. Hungarian Helsinki 
Committee 2018c). The smooth translation of political programs into coherently interpreted case law should thereby be guaranteed. This includes the changes made to the asylum procedure. The affirmation of these changes and a coherent interpretation of lower courts in the application of the new laws should thereby also be guaranteed.

These legal changes amount to an institutional landscape of concentrated power over the lives of refugees. The structures that dominate them only mockingly resemble those of an asylum system that aims at protecting those seeking refuge from war and persecution, while hollowing out those rights. The state has encroached on all matters relating to asylum. It dominates the lives of refugees from the moment they attempt to enter Hungarian territory, curtailing their rights to access, fair legal representation, and a just procedural determination of their asylum claims. Structurally, the institution of asylum is dead in Hungary.

\section{Dominating refugees: human rights abuses}

Yet, we cannot stop here. The complete control over the lives of refugees has a profound impact on their well-being. To see how, we may turn to some of the extrajudicial forms of domination and their results in violating the human rights of refugees in Hungary.

For all those refugees that do not want to wait for an unspecified time and an unspecified chance of entering one of the transit zones, only one option exists: entering Hungarian territory elsewhere. This, however, is connected with severe physical dangers. In addition to the above-mentioned obstacle of surpassing a razor-wire reinforced fence and risking a prison sentence of up to three years if caught, refugees have been faced with yet another form of danger since 2016. A set of laws entered into force in July of that year, creating an $8 \mathrm{~km}$ stretch on the Hungarian side of the border fence within which refugees could be apprehended and pushed back to Serbia without launching an asylum application or following a deportation decision (Hungarian Helsinki Committee 2016b). In 2017, this initial stretch of land was extended to cover the entire territory of the country (Hungarian Helsinki Committee 2017a). These push-backs feature an extraordinary amount of violence. Refugees are fair game after they pass the border in this way. The institutional structures place unchecked power into the hands of the army and a specially established police force that bears the name 'border hunters.' The hunt for refugees, however, is not confined to those bearing the official insignia of the Hungarian state. Private vigilante groups in military garments patrol the border too - condoned by the Hungarian state. They search and seize refugees. Then, they wait for the police or the army. What happens in between is up to them. When the border police arrive, refugees are 'escorted' to the fence and are made to exit to Serbia. The whole process involves physical violence, such as beatings, intimidation with dogs and batons, destruction of property, and treatment demeaning of their human dignity. 
To grasp what such treatment implies and how it occurs, we may turn to the testimony of a refugee so apprehended on May 23, 2016. That his is not a unique treatment, but rather an expression of a systematic abuse of the human rights of refugees, is corroborated by numerous similar accounts of refugees being returned to Serbia (Human Rights Watch 2016a; Hungarian Helsinki Committee 2017b; Médecins Sans Frontieres 2017). In the company of eight other people, the Afghan man was forced to run back to the border fence. He describes what happened as follows:

We were tired but if we lagged behind, they would beat us with their batons to keep us going. They took us back to where we crossed the border and made us stop about 100 meters from the fence. About 30 police were gathered.... They wore dark blue uniforms, there was also one in grey. They told us to sit and put our heads in our hands and not lift our heads to look around. But I managed to see that they brought two big spray canisters from the cars. They started beating us with batons while we sat and stared at the ground. Then they told us to stand up and run up to the fence and they kept beating us as we were running. We came about ten meters from the fence and saw a small hole, full of razor-wire and sharp edges in three layers.

They brought plastic cuffs and tied our hands in front of our bodies. I was the first in line and all of a sudden, a police officer came and sprayed my face. I couldn't see as he made me crawl through the razor-wire, so I cut my leg and hands badly. After that, I was inside the layers of the fence when he started kicking the fence to make the razor injure me. He then kept kicking my butt to make me crawl faster through the fence. My eyes were full of tears and my hands cuffed in front of me. They swore and laughed at me during the whole time.

(Human Rights Watch 2016b)

In 2017 alone, almost 10,000 of such pushbacks have occurred. Over 10,000 refugees attempted to cross the border but were detected and blocked by the police (Hungarian Helsinki Committee 2018d).

The violation of the human rights of refugees is a direct consequence of an institutional landscape that concentrates power and abolishes checks and balances. In such an environment, extrajudicial forms of domination of refugees may thrive without punishment. The climate, in which such forms of extrajudicial violence occur, is one of hostility against refugees and one that arguably supports the creation and the operations of private vigilante groups and violence against refugees. Such climate is created directly on behalf of the Hungarian government - both through a number of public campaigns and a media landscape that nearly exclusively belongs to its supporters. The public campaign vilifying refugees spans a timeline from 2015 until today. Numerous posters were placed throughout the country, instructing locals on the dangers of terrorism, the threat to their jobs and 
their culture that refugees pose. Leaflets were sent to all households, warning the Hungarian populace of 'no-go zones' in European cities with larger proportions of migrants and national consultations were issued to citizens, in which they were asked to condemn the terrorist, monetary, and cultural threat of refugees in a lopsided public vote.

What we witness in Hungary is thus a de facto abolition of the institution of asylum, ${ }^{5}$ accompanied by serious violations of refugees' human rights in a climate of hatred that is spurred by the government itself. All in all, the desire for upholding a norm of closure in the face of a supposedly looming threat of migration is aptly described by prime minister Viktor Orbán himself: 'the question is whether we can keep ourselves out of this, whether we can preserve our culture, our Christian culture, our Hungarian culture and how we live - our way of life.... I do not want Hungary to become an immigrant country’ (Orbán 2018b).

\section{'Let others do the dirty job' or why Germany turns its eyes from human rights violations at the EU periphery}

The position of the German government on asylum appears to be rather different at first sight. In 2015, the German government decided to admit hundreds of thousands of refugees to the country, arguably ignoring the Dublin regulations requiring the first EU country into which refugees enter to process their asylum claims. This decision was accompanied by a largescale public reaction, coining the phrase of a 'welcome culture' (Willkommenskultur) in Germany and the promise that asylum claims would be processed no matter how many persons seek refuge (Funk, 2016; Hamann and Karakayali, 2016). The implied message is clear: Germany remains true to the normative principle underlying its constitutional provision on asylum, even if this requires action beyond the immediate duties laid upon them by EU law. Accordingly, the image created by politicians and reinforced in the public eye is that of a generally virtuous agent - the image of the good Samaritan who commits 'extraordinary acts of generosity' (Stern 2016: 11; Ignatieff 2017: 226) and upholds the rights of refugees no matter how many apply for asylum (see Thränhardt 2018). ${ }^{6}$

This image starkly contradicts the politics of fencing in and keeping refugees out, and we would hence expect the two to clash. In other words, we would expect resistance against the abolition of the institution of asylum and the systematic abuse of human rights at the periphery of the EU. Yet, such resistance may be searched for in vain. No actions were taken, no criticisms muttered. To the contrary, both on the EU level as well as on the level of national politics, German politicians have remained surprisingly supportive of the Hungarian government. Orbán remains a welcome guest to conservative politicians who have not only extended a welcome hand but have praised the Hungarian politics of deterrence and detainment of refugees. 
Likewise, Orbán's party, Fidesz, also remains a member of the European People's Party (EPP) in the European Parliament and, thus, a partner of other conservative parties such as the German Christian Democratic Union (CDU). Members of the German fraction of the EPP have repeatedly and openly supported Orbán's election campaigns, which were focused solely on the promise to keep the borders closed and refugees out, even at the cost of supporting a political regime that seemingly slides into autocracy (see Kelemen 2017). The German members of the EPP have reasserted their support to Fidesz as an ally on the European level (Fekete 2016). Cries for expelling the party have only materialized after the Orbán regime has attacked EPP party members publicly. Refugees and their treatment, however, have not played a role in the discourse on the Fidesz membership in the EPP. Even though the social democrats have bemoaned Orbán's policies towards refugees, they too have not taken action. The sobering fact is that Hungary's policies towards refugees play into the hands of other EU member states such as Germany. They turn their eyes away from the violation of human rights and the abolition of the institution of asylum as long as Hungary's policies keep refugees from their doorsteps. This dynamic constitutes a 'division of labor' in which Hungarian politicians such as Orbán may claim to be the sole protector of a Christian homeland, defending it from the hordes of refugees awaiting to inundate it (cf. Fekete 2016; cf. Kalmar 2018). ${ }^{7}$ Yet, it also allows for the creation of an image of core EU countries, such as Germany, as countries that do not tamper with the right to asylum - that all those who apply for asylum in Germany will receive it, so long as they qualify. The good Samaritan is nothing but an image that is painted while others keep away those asking for help. In return, the policies of sealing the external borders of the EU are supported, and the measures they entail condoned. This has been made expressively clear both in the demands of the Hungarian government for support of doing the dirty job for core EU countries, as well as in the reaction of politicians of the latter. One snippet of such expressive support reads:

And, if you permit, I would like to say one more thing about solidarity; because it does hurt us Hungarians, and we perceive it as unfair that Germany often accuses us as lacking solidarity. I just want to inform you of the fact that, in Hungary, there are 8000 armed men and women who stand and protect the border for 24 hours a day, a border through which migrants, if they succeed, come to Germany. Even if the Turkeydeal exists: If it were not for those armed Hungarians protecting the border, 4000-5000 migrants would arrive in Germany on a daily basis. We protect you. That is solidarity - I think a form of solidarity that is to be taken serious.

(Orbán 2018c) 
The protection of the external borders that Hungary guarantees is acknowledged. There is no question of that. The differences between us exist elsewhere.

(Merkel 2018, own translation)

This form of cooperation keeps refugees from entering the territory of core EU states. As such, it represents just another instrument in keeping refugees at bay. Liberal democracies, such as Germany, have long resorted to a toolbox of instruments that are designed to keep refugees from entering their territory. They have established barriers and placed hurdles in the ways of refugees attempting to enter liberal democracies. They include visa regulations requiring pre-arrival permission to enter a state's territory, which is something that refugees cannot obtain since they are only allowed to launch asylum applications on the territory of a state (Gibney 2006). They also include carrier sanctions, placing high fines on airline companies for transporting any persons without such permissions to enter a state's territory (see also Collinson 1996; Gibney 2006). Combined, they aim at reducing the range of travel options available to refugees, making seeking asylum in liberal democracies more costly and more dangerous. With regular forms of travel being ruled out, refugees turn to smugglers who charge higher prices the more hurdles there are to overcome. Supporting the establishment of barriers and condoning the policies of deterrence and detainment at the EU external borders have a similar effect. They aim at curtailing the onward movement of refugees into the direction of liberal democracies such as Germany. As such, they do not differ in principle from other forms of cooperation these same states maintain with the external neighbors of the EU. Bi- and multi-lateral agreements with states such as Libya and Turkey follow the same logic: keeping refugees from entering in exchange for material and financial support (Bialasiewicz 2012; Rygiel, Baban \& Ilcan 2016).

These measures play into what some have called the hypocrisy of asylum (see Gibney 2014). Liberal democracies, such as Germany, claim to uphold the rights of refugees. They assert that all those fleeing from war and persecution may find refuge in their countries while simultaneously placing hurdles and barriers in their way. The right to seek asylum thus remains, but it remains as a distant possibility, as an illusion of safe haven that refugees may not access. Condoning the violations of human rights and the abolition of the institution of asylum in countries such as Hungary is mere collateral damage to this end. As long as the dirty work is done at the periphery of the EU, states such as Germany turn their eyes away from such violations. After all, they may retain their image as the good Samaritan - a knight in shining armor offering to refugees the utopia of asylum. And a utopia it remains for refugees: a non-place.

\section{Conclusion}

What we are witnessing at the periphery of the EU is the systematic abolition of the institution of asylum. We are witnessing the establishment of 
border fences, detention zones for refugees, and an order inside the country that aims at concentrating unchecked power in the hands of the government in order to dominate the lives of refugees. This has led to pervasive human rights abuses of those who seek refuge from persecution and war. Yet, we are also witnessing the lack of criticism and action by states that proclaim to defend the rights of refugees. In this chapter, I have sought to answer why. I have argued that core EU states profit from the fact that countries at the EU periphery, such as Hungary, are keeping refugees at bay. I have argued that this 'division of labor' allows Hungarian politicians to reap the political fruits of demonizing refugees in claiming to be the sole protectors of a Christian European homeland from being inundated by refugees, while it simultaneously allows core EU states, such as Germany, to foster the image of states upholding the normative core underlying the right to asylum.

What does this imply? It means that we must bid farewell to a simplistic moral picture of asylum policies in contemporary Europe. The norm of closure and the entailed violations of the rights of refugees in Hungary would not be possible without other EU states standing idly by, condoning, or even supporting a halt to refugees turning up at their borders. On the other hand, it also means that the norm of a morally founded right of asylum comes at a price - a price that casts a shadow on a flawless moral self-image.

\section{Notes}

1 For an overview of the situation in Hungary during the long summer of migration, see: Migrant Solidarity Group of Hungary (2016) and Kallius, Monterescu \& Rajaram (2016), for aspects of the situation in Germany, see Herrmann in this volume and Funk (2016) for a brief overview.

2 This included a more-or-less functioning support scheme for refugees, that provided for housing money and allowances. For more on the Hungarian asylum system before 2015, see the Asylum Information Database Report (2015).

3 Cf. Szary \& Giraut (2015) and Kallius, Monterescu \& Rajaram (2016) for conceptions of mobile borders and orders that stretch beyond the demarcation lines.

4 The relevant amendment to the constitution reads: 'Any non-Hungarian citizen arriving to the territory of Hungary through a country where he or she was not exposed to persecution or a direct risk of persecution shall not be entitled to asylum' Art. XIV (4) of the Basic Law of Hungary. See also the Hungarian Helsinki Committee (2018e) for legal practice and the consequences of the legal changes.

5 This does, of course, not mean that asylum has vanished altogether and that no one receives asylum in Hungary any longer. Yet, this privilege is reserved for the friends of the government, such as the former Macedonian Prime Minister, fleeing from criminal prosecution, or to those that fit the narrative of a Hungarian nation protecting white Christian Europeans. To that end, the Hungarian government has provided asylum to fleeing Ukrainians. What this shows is not that asylum is impossible, but that the institution of asylum has vanished - that the procedurally guaranteed and fairly administered right of asylum has been abolished in Hungary. See the statement of the Hungarian Prime Minister's Office with regards to the socalled Gruevski affair (Gulyás 2018). 
6 See also an interview with Merkel in the Rheinische Post, in which she emphasizes that the right of asylum must remain unlimited (Bröcker \& Quadbeck 2015).

7 Cf. ft. 1

\section{References}

Asylum Information Database (2015). Country Report: Hungary. Available at: www. asylumineurope.org/sites/default/files/report-download/aida___hungary_thirdupdate _final_february_2015.pdf.

Asylum Information Database (2017). Country Report: Hungary. Available at: www. asylumineurope.org/sites/default/files/report-download/aida_hu_2017update.pdf.

Basic Law for the Federal Republic of Germany (1949). Germany.

Betts, A. (2015). 'The normative terrain of the global refugee regime,' Ethics $\mathcal{B}$ International Affairs 29(4), pp. 363-375.

Bialasiewicz, L. (2012). 'Off-shoring and out-sourcing the borders of Europe: Libya and EU border work in the Mediterranean,' Geopolitics, 17(4), pp. 843-866.

Binetti Armstrong, A. (2018). 'Cutes and ladders: Nonrefoulement and the Sisyphean challenge of seeking asylum in Hungary,' Columbia Human Rights Law Review 50(2), pp. 46-115.

Bröcker, M. \& Quadbeck, E. (2015). “'Grundrecht auf Asyl kennt keine Obergrenze”: Interview mit Bundeskanzlerin Angela Merkel,' Rheinische Post Online, 11 September. Available at: https://rp-online.de/politik/deutschland/angela-merkel-da s-grundrecht-auf-asyl-kennt-keine-obergrenze_aid-9533771

Collinson, S. (1996). 'Visa requirements, carrier sanctions, "safe third countries" and "readmission": The development of an asylum "buffer zone" in Europe,' Transactions of the Institute of British Geographers 21(1), pp. 76-90.

Fekete, L. (2016). 'Hungary: Power, punishment and the "Christian-national idea",' Race $8 \mathcal{B}$ Class, 57(4), pp. 1-15.

Funk, N. (2016). 'A spectre in Germany: Refugees, a "welcome culture" and an "integration politics",' Journal of Global Ethics 12(3), pp. 289-299.

Gibney, M. J. (2006). “'A Thousand Little Guantanamos:” Western States and Measures to Prevent the Arrival of Refugees,' in Tunstall, K. E. (ed.) Displacement, Asylum, Migration. Oxford and New York: Oxford University Press, pp. 139-169.

Gibney, M. J. (2014). 'Asylum: Principled hypocrisy,' Migration: A Compas Anthology. Oxford: COMPAS.

Gulyás, G. (2018). Statement by the Prime Minister's Office: Asylum request of Nikola Gruevski. Available at: www.kormany.hu/en/prime-minister-s-office/news/statem ent-by-the-prime-minister-s-office-asylum-request-of-nikola-gruevski

Hamann, U. \& Karakayali, S. (2016). 'Practicing Willkommenskultur: Migration and Solidarity in Germany,' Intersections 2(4), pp. 69-86.

Human Rights Watch (2016a). Hungary: Failing to Protect Vulnerable Refugees. Available at: www.hrw.org/news/2016/09/20/hungary-failing-protect-vulnerable-refugees

Human Rights Watch (2016b). Hungary: Migrants Abused at the Border. Available at: www.hrw.org/news/2016/07/13/hungary-migrants-abused-border

Hungarian Helsinki Committee (2015a). No Country for Refugees - New asylum rules deny protection to refugees and lead to unprecedented human rights violations in Hungary. Available at: www.helsinki.hu/wp-content/uploads/HHC_Hungary_Info_Note_Sep t-2015_No_country_for_refugees.pdf 


\section{F. Bender}

Hungarian Helsinki Committee (2015b). Building a Legal Fence: Changes to Hungarian asylum law jeopardise access to protection in Hungary. Available at: www. helsinki.hu/wp-content/uploads/HHC-HU-asylum-law-amendment-2015-Augustinfo-note.pdf

Hungarian Helsinki Committee (2016a). Destitute, but Waiting: Report on the Visit to the Tompa and Röszke 'Pre-Transit Zone' Area on the Hungarian-Serbian Border. Available at: www.helsinki.hu/wp-content/uploads/HHC_Röszke_Tompa_pre_transit_zone_ 22April2016.pdf

Hungarian Helsinki Committee (2016b). Hungary: Latest amendments 'legalise' extrajudicial push-back of asylum-seekers, in violation of EU and international law. Available at: www. helsinki.hu/wp-content/uploads/HHC-info-update-push-backs-5-July-2016.pdf

Hungarian Helsinki Committee (2017a). Hungary: Government's New Asylum Bill on Collective Push-backs and Automatic Detention. Available at: www.helsinki.hu/wp -content/uploads/HHC-Info-Update-New-Asylum-Bill-15.02.2017.pdf

Hungarian Helsinki Committee (2017b). Pushed Back at the Door: Denial of Access to Asylum in Eastern EU Member States. Available at: www.helsinki.hu/wp-content/up loads/pushed_back.pdf

Hungarian Helsinki Committee (2018a). Systemic Violations of Asylum-Seekers' Human Rights in Hungary. Available at: www.helsinki.hu/wp-content/uploads/OSCE-H DIM-2018-statement-Hungary-migration.pdf

Hungarian Helsinki Committee (2018b). Hungarian Government Marks World Refugee Day by Passing Law to Jail Helpers. Available at: www.helsinki.hu/wp-content/uploa ds/HUNGARIAN-GOVERNMENT-MARKS-WORL

D-REFUGEE-DAY-BY-PASSING-LAW-TO-JAIL-HELPERS-20June2018En.pdf

Hungarian Helsinki Committee (2018c). Attacking the Last Line of Defence: Judicial Independence in Hungary in Jeopardy. Available at: www.helsinki.hu/wp-content/up loads/Attacking-the-Last-Line-of-Defense-June2018.pdf

Hungarian Helsinki Committee (2018d). Hungary: Key Asylum Figures for 2017. Available at: www.helsinki.hu/wp-content/uploads/HHC-Hungary-asylum-figures-1-Janua ry-2018.pdf

Hungarian Helsinki Committee (2018e). Asylum-Seekers with Inadmissible Claims Are Denied Food in Transit Zones at Border. Available at: www.helsinki.hu/wp-content/up loads/Denial-of-food-for-inadmissible-claims-HHC-info-update-17August2018.pdf

Ignatieff, M. (2017). 'The refugee as invasive other,' Social Research: An International Quarterly 84(1), pp. 223-231.

Kallius, A., Monterescu, D., \& Rajaram, P. K. (2016). 'Immobilizing mobility: Border ethnography, illiberal democracy, and the politics of the "refugee crisis" in Hungary,' American Ethnologist 43(1), pp. 25-37.

Kalmar, I. (2018). "The battlefield is in Brussels": Islamophobia in the Visegrád Four in its global context,' Patterns of Prejudice 52(5), pp. 1-14.

Kelemen, D. R. (2017). 'Europe's other democratic deficit: National authoritarianism in Europe's democratic union,' Government and Opposition, 52(2), pp. 1-28.

Lázár, J. (2015). Two types of border fence to be built on Serbian-Hungarian border. Available at: www.kormany.hu/en/prime-minister-s-office/news/two-types-of-border-fen ce-to-be-built-on-serbian-hungarian-border

Médecins Sans Frontieres (2017). MSF denounces the widespread violence on migrants and refugees at the Serbian/Hungarian border. Available at: www.msf.org/serbia-msf-de nounces-widespread-violence-migrants-and-refugees-serbianhungarian-border 
Merkel, A. (2015). Summer Press Conference of Angela Merkel. Available at: www.bun desregierung.de/breg-de/aktuelles/pressekonferenzen/sommerpressekonfer enz-von-bundeskanzlerin-merkel-848300

Merkel, A. (2018). Pressekonferenz von Bundeskanzlerin Merkel und dem ungarischen Ministerpräsidenten Viktor Orbán. Available at: www.bundeskanzlerin.de/bkin-de/a ktuelles/pressekonferenz-von-bundeskanzlerin-merkel-und-dem-ungarischen-minis terpraesidenten-viktor-orbán-1511460

Migrant Solidarity Group of Hungary (2016). Hungary's Long Summer of Migration. Available at: www.migszol.com/files/theme/Report/migszol_report_eng.pdf

Nagy, B. (2016). 'Hungarian Asylum Law and Policy in 2015-2016: Securitization instead of loyal cooperation,' German Law Journal 17(6), pp. 1033-1082.

Orbán, V. (2018a). 'State of the Nation' address. Budapest. Available at: www.korma ny.hu/en/the-prime-minister/the-prime-minister-s-speeches/viktor-orban-s-sta te-of-the-nation-address

Orbán, V. (2018b). Let us protect Hungary from becoming an immigrant country. Available at: www.kormany.hu/en/the-prime-minister/news/let-us-protect-hungary-from-becom ing-an-immigrant-country

Orbán, V. (2018c). Pressekonferenz von Bundeskanzlerin Merkel und dem ungarischen Ministerpräsidenten Viktor Orbán. Available at: www.bundeskanzlerin.de/bkin-de/a ktuelles/pressekonferenz-von-bundeskanzlerin-merkel-und-dem-ungarischen-minis terpraesidenten-viktor-orbán-1511460

Rygiel, K., Baban, F., \& Ilcan, S. (2016). 'The Syrian refugee crisis: The EU-Turkey “deal” and temporary protection,' Global Social Policy 16(3), pp. 315-320.

Stern, R. T. (2016). 'Responses to the "refugee crisis": What is the role of self-image among EU countries?' European Policy Analysis 10, pp. 1-16.

Szary, A.-L. A. \& Giraut, F. (2015). 'Borderities: The politics of contemporary mobile borders,' in Szary, A.-L. A. \& Giraut, F. (eds) Borderities and the Politics of Contemporary Mobile Borders. London: Palgrave Macmillan, pp. 1-19.

Thränhardt, D. (2018). 'Welcoming citizens, divided government, simplifying media: germany's refugee crisis, 2015-2017,' in Dell'Orto, G. \& Wetzstein, I. (eds) Refugee News, Refugee Politics: Journalism, Public Opinion and Policymaking in Europe. London: Routledge.

Umek, D., Minca, C. \& Šantić, D. (2019). 'The refugee camp as geopolitics: The case of Preševo (Serbia),' in Paradiso, M. (ed.) Mediterranean Mobilities: Europe's Changing Relationships. New York: Springer, pp. 37-53. 